\title{
Pelos serviços prestados: o perfil do escravo alforriado em Mariana no período 1840-1888
}

\author{
Heloísa Maria Teixeira \\ Pós-Doutoramento - Faculdade de Economia, Administração e Contabilidade (FEAVUSP) \\ E-mail: heloisate@hotmail.com \\ Recebido em 23 de julho de 2013. Aceito em 18 de novembro de 2014.
}

\section{Resumo}

As cartas de alforria geralmente traziam prenome, idade, cor e naturalidade referentes aos escravos alforriados. Elas poderiam conter ainda informações sobre o estado civil, a filiação, a ocupação e o valor dos escravos. Através dessas informações e da análise quantitativa, traçamos o perfil do escravo libertado em Mariana (região economicamente voltada para a produção de alimentos) verificando se as características do alforriado modificaram-se ao longo do tempo durante o período 1840-1888, buscando apreender as transformações na concessão da manumissão no contexto das leis abolicionistas.

\section{Palavras-Chave}

Escravidão. Alforrias. Leis abolicionistas. Economia de subsistência.

\begin{abstract}
The letters of enfranchisement used to exhibit name, age, color and birthplace of freed people. They also could bring information about the marital status, parentage, occupation and financial value of the slaves. These data and its quantitative analysis allow us to draw the emancipated population profile of Mariana la subsistence economy area) in order to verify the changes on freed characteristics from 1840 to 1888 and to realize the transformations on the practices of granting freedom, regarding the abolitionist laws period.
\end{abstract}

\section{Keywords}

Slavery. Manumissions. Abolitionist laws. Subsistence economy.

\section{JEL Classification}

N36.

- A autora agradece à Fundação de Amparo à Pesquisa do Estado de São Paulo (FAPESP) pelo apoio financeiro e ao professor Nelson Nozoe pela supervisão deste trabalho. 


\section{Introdução}

Em 1850, a lei que proibiu o tráfico africano inaugurou o declínio do sistema escravista no Brasil. A partir de então, tem-se constante diminuição do número de cativos no Brasil, o que resultou em grande movimentação interna em busca da mão de obra escrava residente no país, mormente das regiões menos mercantilizadas para aquelas voltadas para o mercado externo. Outra forma de aumentar o número de cativos seria a reprodução endógena. No entanto, em 21 de setembro de 1871, a legislação causou ainda mais embaraço ao sistema escravista. A partir daquela data, crianças que nascessem de ventre escravo seriam declaradas livres. A mesma lei permitiu ao cativo a acumulação de pecúlio para ser usado na compra da própria alforria e ainda instituiu um fundo que tinha como propósito a emancipação de mancípios. O Estado passou, portanto, a mediar as relações entre escravos e senhores, ampliando, assim, a esperança da conquista da liberdade. A intervenção do Estado na relação senhor/escravo foi reforçada pela Lei de 1885, conhecida como Lei dos Sexagenários, que, além de libertar os escravos com mais de 65 anos, fixava o valor máximo que os escravos poderiam atingir nas negociações de vendas ou emancipações.

Através da análise de 425 cartas de liberdade registradas nos cartórios dos I e II ofícios do termo de Mariana, descreveremos o padrão do alforriado para o período 1840-1888, buscando apreender as transformações de paradigmas no contexto das leis abolicionistas. ${ }^{1}$ Nosso marco inicial, 1840, justifica-se por ser a década que antecede a proibição efetiva do tráfico internacional de escravos. A análise das alforrias para os anos 1840 permite-nos estabelecer uma comparação com as décadas subsequentes e, assim, dimensionar o impacto causado pelas leis abolicionistas na política de alforrias.

A localidade de Mariana encontrava-se, durante o período 18401888, envolta em intensa diversificação de atividades econômicas. A predominância era daquelas ligadas às atividades agrícolas e pastoris, mas também havia propriedades ocupadas com a mineração e a siderurgia. Observando os inventários post-mortem da época, constatamos que, entre os gêneros cultivados, destacavam-se a produção

1 Em nosso auxílio, para importantes análises comparativas e associativas, recorremos aos 522 inventários post-mortem levantados no I ofício do termo de Mariana para todo o período em questão. Utilizamos o banco de dados construído para nossa pesquisa de mestrado e que abrangia o período de 1850 a 1888; a ele somamos os dados, ora levantados e coletados, de 129 inventários registrados nos anos 1840-1849. 
de gêneros de primeira necessidade - milho, arroz, feijão, açúcar, etc. - e o café. Nas atividades pastoris disseminadas por todas as freguesias, predominava a criação de porcos, seguida pela de bovinos e equinos. Era comum a conjugação de várias culturas e também a criação de animais nas propriedades marianenses (Teixeira, 2001).

\section{Alforrias em Mariana (1840-1888)}

A carta de alforria era um documento no qual o proprietário do escravo identificava-se e, em seguida, descrevia informações sobre o escravo que seria libertado. Em geral, fornecia nome, idade, cor, estado civil, filiação, naturalidade, além das condições da alforria. Em algumas ocasiões, trazia também a ocupação do cativo.

Boa parte destas cartas era registrada em cartórios, oficializando a liberdade do escravo. Esse recurso protegia não só o liberto, mas também o senhor: para o primeiro, o registro evitava possíveis contestações quanto à vontade do proprietário, principalmente por parte dos herdeiros, além de evitar a escravização de libertos; para o segundo, o registro resguardava os termos acertados com o ex-escravo, facilitando a cobrança do cumprimento das condições impostas. Por suas características, as cartas de liberdade constituem-se em fontes privilegiadas pelo fato de possibilitarem um estudo quantitativo das variáveis associadas ao estudo das manumissões - idade, sexo, cor, origem, estado civil, filiação, qualificação profissional, condições da alforria, etc. - e também por fornecer informações que permitem reconstituir os principais mecanismos que presidiam a política de manumissões. Permitiu-nos, ainda, analisar os ritmos das alforrias durante a segunda metade do século XIX.

Também realizamos estudos de caso significativos para a compreensão da política de aforramento. Conforme salienta Andréa Lisly Gonçalves, alcançar a alforria "poderia ter significados tão diferentes quanto as particularidades registradas no ato de alforriar, o que tornava cada manumissão, praticamente, um caso singular" (Gonçalves, 2011, p.20). A metodologia, portanto, recorre principalmente aos métodos quantitativos, sem, contudo, a eles se restringir. Ao contrário, a análise qualitativa é valiosa para percepção mais apurada da política de alforrias praticada pelos senhores. 
Observando a concessão das alforrias ao longo do período 1840-1888, construímos o Gráfico 1.

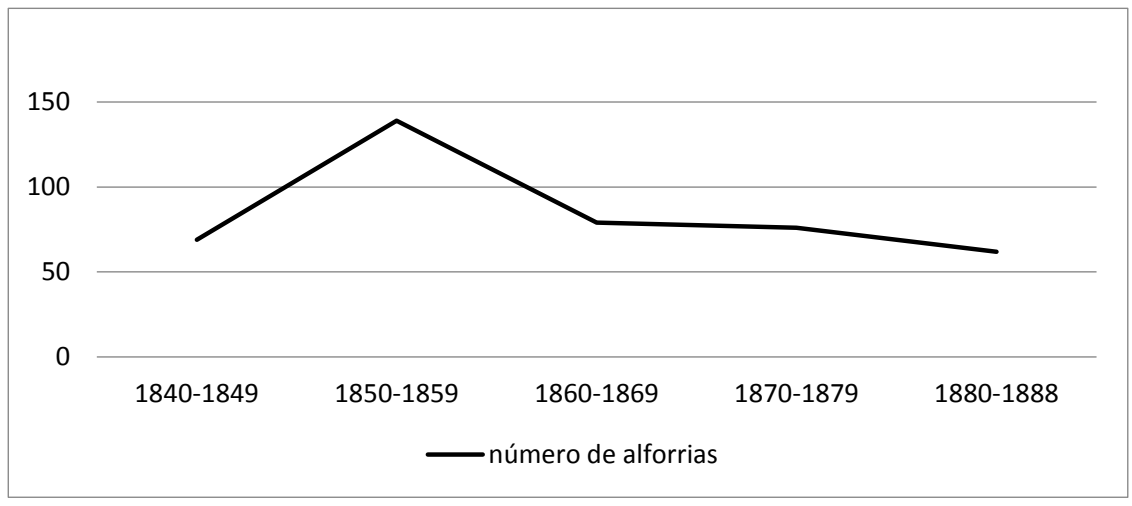

Gráfico 1 - Cartas de alforrias registradas em cartórios (Mariana 1840-1888)

A curva do Gráfico 1 revela acentuada queda do número de registros de alforrias entre as décadas de 1850 e $1860 .^{2}$ Nas décadas seguintes, a tendência é a mesma, porém, de forma menos pronunciada. Podemos associar o movimento do Gráfico 1 à lei que proibia a entrada de escravos africanos nos portos brasileiros. Conforme revela-nos a historiografia, a Lei Eusébio de Queiroz resultou em quase imediata elevação de preços dos cativos (o que tornou a compra da liberdade ainda mais difícil para aqueles que vinham economizando) e em intenso tráfico interno que deslocou escravos das regióes menos mercantilizadas para aquelas envolvidas com a economia de exportação, ${ }^{3}$ reduzindo, em associação direta, o número de alforrias nas áreas de economia voltada para o mercado interno. Percebemos, de maneira geral, uma diminuição dos inventários post-mortem contendo escravos em Mariana entre 1840 e 1888 (Tabela 1). Comparadas as décadas de 1840 e 1850, decresce de forma significativa o número de escravos arrolados nos inventários, porém essa redução torna-se menos acentuada estando em cotejo as décadas seguintes. Nos últimos anos da escravidão, o número de inventários que continham

2 Para a década de 1840, apenas um livro de notas com registros de cartas de alforria foi encontrado para o I Ofício e nenhum para o II. Os registros de alforria nos 1840, portanto, estão em menor número em relação às décadas posteriores. O que pudemos averiguar no catálogo de documentação da Casa Setecentista de Mariana é que há, pelo menos, mais dois livros de notas que abrangiam a década de 1840, mas que, infelizmente, estão interditados para consulta.

3 Sobre o mercado interno, ver: Slenes, 1986; Machado, 2002; Flausino, 2006; Motta, 2006. 
escravos sofre uma queda abrupta e, por consequência, o número de escravos cai vertiginosamente.

Tabela 1 - Inventários post-mortem que continham escravos - Mariana (18401888)

\begin{tabular}{ccc}
\hline Décadas & Número de inventários & Número de escravos \\
\hline $1840-1849$ & 129 & 1471 \\
\hline $1850-1859$ & 136 & 1195 \\
\hline $1860-1869$ & 111 & 1143 \\
\hline $1870-1879$ & 108 & 1101 \\
\hline $1880-1888$ & 38 & 356 \\
\hline Total & $\mathbf{5 2 2}$ & $\mathbf{5 2 6 6}$ \\
\hline
\end{tabular}

A análise da estrutura de posse (Tabela 2) permite-nos observar que as grandes escravarias, embora compusessem menos de 30\% do total, possuíam 69,9\% dos escravos descritos nos inventários. Em sentido oposto, as escravarias com apenas um escravo detinham 1,3\% do total dos escravos arrolados. As escravarias contendo entre dois e cinco escravos, embora estivessem em maior porcentagem $(35,4 \%)$, possuíam apenas $11,2 \%$ dos escravos. As posses contendo entre seis e dez escravos (23,4\%, do total das escravarias) continham $17,6 \%$ da população escrava amostrada. Tais referências tornam a concentração escrava evidente, pois, mesmo somando as três primeiras categorias de posse escrava, que representavam $72 \%$ das escravarias, a porcentagem de cativos era de $30,1 \%$.

Tabela 2 - Estrutura de posse escrava - Mariana (1840-1888)

\begin{tabular}{lccccc} 
& \multicolumn{5}{c}{ Tamanho das escravarias } \\
\cline { 2 - 6 } & $\mathbf{1}$ & $\mathbf{2 - 5}$ & $\mathbf{6 - 1 0}$ & + de 10 & Total \\
\hline \multirow{2}{*}{$\%$ de plantéis } & 69 & 185 & 122 & 146 & 522 \\
& $(13,2 \%)$ & $(35,4 \%)$ & $(23,4 \%)$ & $(28,0 \%)$ & $(100 \%)$ \\
\hline \multirow{2}{*}{$\%$ de escravos } & 69 & 591 & 925 & 3681 & 5266 \\
& $(1,3 \%)$ & $(11,2 \%)$ & $(17,6 \%)$ & $(69,9 \%)$ & $(100 \%)$ \\
\hline
\end{tabular}

Fonte: Inventários post-mortem - Mariana (1840-1888)

Antes do fim do tráfico internacional, Mariana parece ter recorrido com surpreendente frequência à compra de africanos. Boa parte da população cativa $(28,6 \%)$ descrita nos inventários dos anos 1840 era formada por homens oriundos de ultramar. Essa intensa participação 
tem queda significativa nos anos seguintes: $15,0 \%$ na década de 1850 ; $14,6 \%$ nos anos $1860 ; 6,4 \%$ nos 1870 ; e $5,1 \%$ nos 1880 .

A diminuição do número de inventários que continham escravos ao longo das décadas sugere que a mão de obra mancípia estava em queda nas propriedades marianenses. ${ }^{4}$ Parte desse declínio provavelmente seja em decorrência da transferência de escravos para outras localidades, entretanto, também devemos ressaltar os efeitos das leis de 1871 e 1885.

A diminuição do contingente cativo após 1850, seja por efervescência do tráfico interno, seja por inoperância do tráfico internacional nos portos do país, é o mais óbvio motivo do decrescimento das alforrias ao longo da segunda metade do século XIX em Mariana; contudo, devemos lembrar que a concessão da liberdade tornou-se mais custosa devido à maior dificuldade na reposição da mão de obra. As ações de liberdade abertas em Mariana, nas últimas décadas do século XIX, além de refletirem o sentimento abolicionista, traduziam também a resistência dos proprietários marianenses em se desfazer de sua mão de obra. Sabemos que a maioria dessas ações arrastouse no tempo, tornando-se volumosos processos (muitas vezes sem desfecho) devido à luta acirrada entre escravos que se consideravam vivendo em injusto cativeiro e escravistas que buscavam manter a propriedade (Teixeira, 2012; Teixeira, 2008).

A mesma situação foi percebida em regiões de mais diferentes configurações econômicas, contanto que não exportadoras. Analisando as alforrias para a cidade de São Paulo durante o século XIX, Enidelce Bertin também encontrou diminuição dos registros das cartas de

4 São raras as fontes que nos informam acerca do número de escravos que viviam e Mariana no século XIX. Alguns mapas e listas de habitantes para distritos que faziam parte do Termo de Mariana foram produzidos para as décadas de 1830 e 1840, porém sem conseguir abranger o território como um todo (Martins, 2002). Encontramos algumas listas de habitantes produzidas para as freguesias marianenses para os anos de 1854 e 1855, porém também não abrangem todo o território do termo. O Censo nacional de 1872 calculou a população escrava que vivia em Mariana em 8.422 cativos (DGE - Recenseamento Geral do Império de 1872). Para o ano de 1880, o Relatório de Presidente de Província registrou uma população servil de 5.426 (Relatório de Presidente de Província, 1880, p. 25-26. Disponível em: <http://www.uchicago.edu/info/brazil/index.html>). Já no ano de 1884, o presidente da província Antonio Gonçalves Chaves mencionou uma população cativa de 4.733 escravos em Mariana (Relatório de Presidente de Província, 1884, p. 63-64. Disponível em: $<$ http://www.uchicago.edu/info/brazil/index.html>). Às vésperas da abolição, no ano de 1887, o relatório de província informou que existiam em Mariana 4.565 cativos (Relatório de Presidente de Província, 1887, p. 32-33. Disponível em: <http://www.uchicago.edu/info/brazil/index.html>). Ressaltamos que, além do tráfico interno, as leis abolicionistas e os índices de mortalidade também devem servir de parâmetros para pensarmos na diminuição da população escrava em Mariana. 
liberdade após o ano de $1850 .{ }^{5}$ Para a autora, a queda do número de registros de alforrias estava atrelada ao encolhimento do contingente escravo na cidade de São Paulo.

A extinção do tráfico africano em 1850 e a consequente busca por escravos no mercado interno contribuíram para alterar de alguma forma a presença escrava na cidade. Primeiramente porque as vendas de escravos para os fazendeiros tornaram-se uma oportunidade de negócio para os proprietários urbanos que quisessem se desfazer de algum cativo - o que teria sido um dos fatores de diminuição da população escrava na cidade. (Bertin, 2004, p.49)

Andrea Lisly Gonçalves, estudando as alforrias na comarca de Ouro Preto do período 1808-1870 - região que esteve no centro das atividades mineradoras do século XVIII e que, no século XIX, embora ainda mantivesse exploração mineradora considerável, ganhava força com a produção e o comércio de gêneros alimentícios para o mercado interno -, também observou diminuição do número de cartas a partir da década de 1830, tornando-se mais acentuada a partir de 1850 . Para a autora, a redução do número de registros estava atrelada à cessão do tráfico internacional de escravos - iniciada em 1830 e definida em 1850 - e o consequente aumento do preço do escravo (Gonçalves, 2011).

Em contrapartida, nas regiões economicamente mais dinâmicas, o movimento das alforrias durante a segunda metade do século XIX é inverso. Lizandra Meyer Ferraz, baseada em extensa documentação (testamentos, inventários post-mortem, autos de prestação de contas testamentárias e cartas de alforria), analisou as alforrias em Campinas em dois períodos (1836-1845 e 1860-1871) e constatou

5 Enidelce Bertin estudou as cartas de alforria para a cidade de São Paulo do período 1800-1888. No total, a autora analisou 1.105 cartas correspondentes a 1.338 escravos. Objetivando melhor compreensão das alforrias no contexto político da escravidão nos Oitocentos, a autora, baseando-se na legislação abolicionista, considerou três recortes cronológicos: 1800-1849, 1850-1870, 1871-1888. Das 1.105 cartas analisadas pela autora, 917 foram registradas no período 1800-1849; 221 no período 1850-1870 e 162 no período 1871-1888. Segundo Bertin, "a maior incidência de cartas de liberdade na primeira metade do século indica a força da prática costumeira de alforriar, mesmo antes das pressões legais ou da campanha abolicionista. A queda nas alforrias na segunda metade do século teria sido efeito da crise na oferta de mão de obra a partir da lei de 4 de setembro de 1850" (Bertin, 2004, p.69-70). 
que, após a proibição da entrada de africanos escravizados, houve aumento das alforrias, sobretudo para as grandes escravarias. Para Ferraz,

o aumento nesta frequência deve estar ligado à adoção de uma política senhorial de controle tanto da população cativa (através da expectativa de liberdade) quanto da população liberta (através do recurso da gratidão) numa época em que os primeiros sinais do fim da escravidão já estavam sendo soados. (Ferraz, 2006, p.87)

Antônio Henrique Duarte Lacerda analisou os padrões de alforria para a região cafeeira de Juiz de Fora do período 1844-1888 através de 744 cartas de liberdade. Segundo o autor, deste total, $56,71 \%$ foram concedidas no período 1844-1880, e 43,29\%, nos últimos anos do período escravista, ou seja, entre 1881 e 1888 (Lacerda, 2006, p.63). Os dados de Lacerda aproximam-se dos estudos historiográficos que apontam a década de 1880 como o momento quando ocorreram mais alforrias, muitas delas coletivas.

Peter Eisenberg, examinando 2.093 papéis de liberdade que alforriaram 2.277 escravos em Campinas entre os anos de 1798 e 1888 - período de expansão da economia açucareira e cafeeira na região -, encontrou um aumento do número das manumissões ao longo dos anos, sendo que, nas décadas de 1870 e 1880, as alforrias dispararam, enquanto a população escrava entrou em declínio, consequência da legislação e das campanhas abolicionistas que se intensificaram nas últimas décadas do século XIX. ${ }^{6}$ Em Campinas, até a década de 1870, dois terços das manumissões onerosas (maioria entre as alforrias) especificavam um prazo de trabalho para os escravos que, muitas vezes, iam até a morte do senhor ou dos seus herdeiros. A partir de 1870, a alforria com prestação de serviços tornou-se ainda mais comum entre as alforrias onerosas e adquiriu semelhança a um contrato de traba-

\footnotetext{
6 Pelas médias anuais de manumissões para o período estudado, podemos perceber o aumento do número de alforrias constatado por Eisenberg: no período 1798-1808, a média era de 1,3 alforria/ano; nos anos de 1809-1818, cresceu para 2,8; nos anos 1819-1828, a média foi de 3,0 alforrias/ano; nos anos 1829-1838, 5,5 alforrias/ano; nos anos 1839-1848, a média foi de 9,1; nos anos 1849-1858, de 7,1; para o período 1859-1868, a média anual foi de 14,1; para 1869-1878, 32,9; e, para 1879-1888, a média subiu extraordinariamente, atingindo a marca de 161,9 alforrias por ano (Eisenberg, 1987, p.181).
} 
1ho, constando nas cartas, além dos prazos limitados para prestação de serviços, a menção de salários pagos aos cativos (Eisenberg, 1987, p.201-202). Já nos anos 1880, cresceu o número de alforrias gratuitas, assim como as alforrias coletivas. Segundo Eisenberg, naquele momento a concessão de alforrias gratuitas funcionou como

uma maneira de continuar a relação entre ele, dono dos meios de produção, e o liberto, fornecedor de força de trabalho, quando não como um simples ato de venda, agora o senhor usou a alforria gratuita como um instrumento político para lidar com a crise social da abolição. Talvez com medo de ser atropelado pelos diversos grupos sociais hostis ou indiferentes à sobrevivência da escravidão, o senhor de escravo em Campinas abandonou o moroso processo legislativo como meio preferido para extinguir a instituição, e distribuía alforrias gratuitamente e em abundância. (Eisenberg, 1987, p.213)

\section{O perfil do escravo alforriado em Mariana durante o período 1840-1888}

A maioria das 425 cartas da nossa amostragem $(85,9 \%)$ referia-se à concessão de liberdade de um escravo. Apenas em três cartas, o número foi superior a nove escravos. Conforme revela a Tabela 3, as cartas traziam informações sobre a alforria de 569 cativos, sendo 265 homens, o que correspondia a $46,6 \%$ do total dos alforriados, e 304 mulheres, ou $53,4 \%$.

Tabela 3 - Escravos alforriados segundo o registro das cartas de liberdade (Mariana, 1840-1888)

\begin{tabular}{c|c|c|c}
\hline $\begin{array}{c}\text { Número de escravos } \\
\text { por carta de liberdade }\end{array}$ & $\begin{array}{c}\text { Número de cartas } \\
\text { de alforria }\end{array}$ & $\%$ & Total de escravos \\
\hline 1 & 365 & 85,9 & 365 \\
\hline $2-5$ & 53 & 12,5 & 138 \\
\hline $6-9$ & 4 & 0,9 & 27 \\
\hline 10 ou mais escravos & 3 & 0,7 & 39 \\
\hline Total & 425 & 100 & 569 \\
\hline
\end{tabular}


As cartas de alforria geralmente traziam prenome, idade, cor e naturalidade referentes aos escravos alforriados. Elas poderiam conter ainda informações sobre o estado civil, a filiação, a ocupação e o valor dos escravos. Através dessas informações e da análise quantitativa, traçamos abaixo o perfil do escravo libertado em Mariana, verificando se as características do alforriado modificaram-se ao longo do tempo. A escravaria que vivia nas propriedades marianenses configuravase pela passagem de uma população caracteristicamente reproduzida por tráfico (alta razão entre os sexos, alta porcentagem de africanos) para, ao longo do período estudado, um conjunto com atributos de reprodução endógena (baixa razão entre os sexos, baixa porcentagem de africanos). Por todo o lapso temporal, contudo, foi observada a alta participação de crianças, o que nos sugere que, mesmo durante o momento de maior movimentação do tráfico, a reprodução endógena não deixou de existir como estratégia de manutenção do grupo.

Segundo a historiografia, independente de local e período, ocorria o seguinte padrão entre os alforriados: predomínio de mulheres (embora fossem minoria entre os escravos); mais crioulos em relação aos africanos; maior incidência de população parda; elevado percentual de velhos e inválidos. ${ }^{7}$ Peter Eisenberg, estudando as alforrias em Campinas durante o século XIX, reforça alguns destes traços, mas busca matizá-los, mostrando como ao longo do século XIX mudaram as motivações e, consequentemente, o perfil do libertando. Assim, até 1870,

enquanto a maioria da população escrava era masculina, negra, crioula, nas idades produtivas e empregada como mão de obra não qualificada, as alforrias registradas foram desproporcionalmente distribuidas entre escravas mulatas, crioulas, muito jovens ou, em menor grau, muito velhas, empregadas no serviço doméstico. (Eisenberg, 1987, p.292)

Para as últimas décadas da escravidão, Eisenberg observou mudanças neste perfil que o fizeram mais próximo daquele da maioria da população escrava:

Embora a economia local tenha experimentado uma prosperidade baseada no café, o número de alforrias aumentou bem mais rapidamen-

7 Gorender, 1985; Luna \& Klein, 2010; Eisenberg, 1987. 
te do que a população escrava, e o indivíduo alforriado foi majoritariamente um escravo homem, negro e, por força das leis de 1850, 1871 e 1885, um crioulo na faixa etária mais produtiva de 11 a 49 anos. (Eisenberg, 1987, p.299-300). ${ }^{8}$

A Tabela 4 demonstra a distribuição de alforrias entre os sexos ao longo do período 1840-1888. As mulheres (com exceção dos anos 1870) foram ligeiramente predominantes entre os libertos, e esta proporção pouco variou ao longo das décadas. Analisando a totalidade das cartas registradas, as mulheres compunham 53,4\% dos agraciados com a carta de alforria, enquanto os homens representavam $46,6 \%$.

Tabela 4 - Alforriados segundo o sexo em Mariana ao longo do período 18401888

\begin{tabular}{c|c|c|c}
\hline Décadas & Homens & Mulheres & Total \\
\hline $1840-1849$ & $\begin{array}{c}49 \\
(45,4 \%)\end{array}$ & $\begin{array}{c}59 \\
(54,6 \%)\end{array}$ & 108 \\
\hline $1850-1859$ & $\begin{array}{c}80 \\
(45,2 \%)\end{array}$ & $\begin{array}{c}97 \\
(54,8 \%)\end{array}$ & 177 \\
\hline $1860-1869$ & $\begin{array}{c}49 \\
(46,7 \%)\end{array}$ & $\begin{array}{c}56 \\
(53,3 \%)\end{array}$ & 105 \\
\hline $1870-1879$ & $\begin{array}{c}52 \\
(51,5 \%)\end{array}$ & $\begin{array}{c}49 \\
(48,5 \%)\end{array}$ & 78 \\
\hline $1880-1888$ & $\begin{array}{c}35 \\
(44,9 \%)\end{array}$ & $\begin{array}{c}(55,1 \%) \\
304 \\
(53,4 \%)\end{array}$ & 569 \\
\hline Total & $\begin{array}{c}265 \\
(46,6 \%)\end{array}$ & &
\end{tabular}

Traçamos o perfil demográfico da população escrava de Mariana para o período 1840-1888. Para essa empreitada, trabalhamos com uma amostragem - extraída dos inventários post-mortem - de 5.266 escravos, sendo 2.986 do sexo masculino ( $56,7 \%$ do total) e 2.280 do

8 Enidelce Bertin, estudando 1.105 cartas correspondentes às alforrias de 1.338 escravos para a cidade de São Paulo do período 1800-1888, encontrou a maioria das cartas sendo concedida às mulheres. Enquanto elas representavam 58,3\% dos alforriados, os homens eram 41,7\% (Bertin, 2004, p.109). No entanto, distribuindo os alforriados segundo o sexo em três subperíodos 1800-1850, 1850-1871 e 1871-1888 - a autora constatou que, embora a superioridade do número das alforrias para as escravas ocorresse nos três momentos, a diferença entre os alforriados do sexo feminino e os do sexo masculino diminuiu. No primeiro subperíodo (1800-1850), elas eram $60,4 \%$ do total de alforriados; no subperíodo $1850-1871$ representaram 57,8\%; e, em 1871-1888, eram 51,7\% (Bertin, 2004, p.76-78). 
sexo feminino $(43,3 \%)$. Essas porcentagens são proporcionalmente inversas às relativas às alforrias, ou seja, embora em menor número na população total, as mulheres conquistavam com maior facilidade a carta de liberdade. Conforme vemos pela Tabela 5, a superioridade numérica dos homens no contingente escravo é observada para todas as décadas - sendo a maior participação nos anos 1840-1849, com o tráfico internacional ainda vigente -, assim como a maior probabilidade de as mulheres alcançarem a alforria também é constatada em todas as décadas, à exceção dos anos 1870-1879.

Tabela 5 - Populações escrava e alforriada ao longo do período 1840-1888, segundo o gênero

\begin{tabular}{ccccc}
\hline \multirow{2}{*}{ Décadas } & \multicolumn{2}{c}{$\begin{array}{c}\text { Contingente escravo segundo } \\
\text { inventários post-mortem }\end{array}$} & \multicolumn{2}{c}{$\begin{array}{c}\text { Contingente alforriados segundo } \\
\text { cartas de liberdade }\end{array}$} \\
\cline { 2 - 5 } & Homens & Mulheres & Homens & Mulheres \\
\hline \multirow{2}{*}{$1840-1849$} & 881 & 590 & 49 & 59 \\
& $(59,9 \%)$ & $(40,1 \%)$ & $(45,4 \%)$ & $(54,6 \%)$ \\
\hline \multirow{2}{*}{$1850-1859$} & 667 & 528 & 80 & 97 \\
& $(55,8 \%)$ & $(44,2 \%)$ & $(45,2 \%)$ & $(54,8 \%)$ \\
\hline \multirow{2}{*}{$1860-1869$} & 669 & 474 & 49 & 56 \\
& $(58,5 \%)$ & $(41,5 \%)$ & $(46,7 \%)$ & $(53,3 \%)$ \\
\hline \multirow{2}{*}{$1870-1879$} & 580 & 521 & 52 & 49 \\
& $(52,7 \%)$ & $(47,3 \%)$ & $(51,5 \%)$ & $(48,5 \%)$ \\
\hline \multirow{2}{*}{$1880-1888$} & 189 & 167 & 35 & 43 \\
& $(53,1 \%)$ & $(46,9 \%)$ & $(44,9 \%)$ & $(55,1 \%)$ \\
\hline \multirow{2}{*}{ Total } & $\mathbf{2 . 9 8 6}$ & $\mathbf{2 2 8 0}$ & $\mathbf{2 6 5}$ & $\mathbf{3 0 4}$ \\
& $(\mathbf{5 6 , 7 \% )}$ & $(\mathbf{4 3 , 3} \%)$ & $(46,6 \%)$ & $(\mathbf{5 3 , 4 \% )}$ \\
\hline
\end{tabular}

A maior probabilidade de as escravas conquistarem a alforria, embora em menor número na população cativa, foi destacada por Francisco Vidal Luna e Herbert Klein que, elencando um grande número de estudos dedicados à questão para vários espaços territoriais ao longo dos séculos XVIII e XIX, revelam que, com raríssimas exceções, a maioria dos alforriados era composta por mulheres (Luna \& Klein, 2010, p.278). Analisando as cartas de alforrias registradas no período 1870-1888, na localidade de Rio das Contas, situada no Alto Sertão Baiano e voltada para o cultivo de gêneros de subsistência, criação de gado e tropeirismo, Maria de Fátima Pires encontrou dados próximos aos que averiguamos para Mariana. Segundo a autora, os homens equivaliam a $44,7 \%$ das alforrias enquanto as mulheres eram $55,3 \%$. Considerando uma amostragem obtida para o período 1860-1888 através de inventários post-mortem, a autora constatou que os homens 
estavam em ligeira vantagem numérica entre os escravos arrolados. Do total de 1.710 cativos inventariados, 606 eram mulheres e 612 eram homens. Entretanto, esse equilíbrio poderia ser alterado caso fosse explicitado o sexo das 418 crianças e 74 idosos. Para Maria de Fátima Pires, um aspecto que explica a superioridade das mulheres entre os alforriados seria o valor das alforrias, menor entre as escravas. Examinando os livros de notas do tabelionato de Rio das Contas para a década de 1870, Pires calculou que, entre os escravos alforriados mediante pagamento, a média de preço para as mulheres foi de Rs. $496 \$ 000$, e para os homens, Rs. $778 \$ 000$. Na década de 1880 , a média do valor das alforrias foi de Rs. $299 \$ 000$ para as mulheres e Rs. 490\$000 para os homens (Pires, 2006, 165).

Kátia Mattoso, buscando explicar a maior participação das mulheres entre as cartas de alforria em Salvador do século XIX, ressaltou que, muitas das vezes, o menor preço das cativas era resultado da maior proximidade delas com seus senhores. Segundo Mattoso,

as cartas de alforria outorgadas a um preço baseado na estima entre proprietário e escravo subvalorizam o cativo, enquanto o preço dos demais se mantém próximo da cotação do mercado de mão de obra servil. (Mattoso, 1990, p.183)

Comparando os preços médios das escravas inventariadas em Mariana com os valores das alforrias registradas, vimos que os preços descritos nos inventários eram, em geral, maiores que os descritos nas cartas, entretanto, nossa amostragem foi pequena, pois apenas 27 mulheres tiveram idade e valor descritos nas cartas de alforria. A diferença entre o valor das alforrias e o preço médio das escravas nos inventários (considerando, claro, idade e ano em que viviam) mostrou variações muito grandes. Em algumas situações, essa diferença ultrapassou os $400 \%$. Maria Joaquina, de 17 anos, foi alforriada em 1864 sob a condição do pagamento da quantia de Rs. $250 \$ 000,{ }^{9}$ entretanto o preço médio para cativas nessa mesma idade nos inventários do período foi de Rs. $1.005 \$ 435$. Várias hipóteses podem ser aventadas em ocasiões como esta: a escrava poderia ter alguma deficiência ou doença, ser de muito alta estima para seus

9 Arquivo da Casa Setecentista de Mariana (CSM), I ofício, livro de notas número 118 (18641868), folha.62. 
senhores, ou ter parte de seu valor já negociada em ocasião anterior. De qualquer forma, é apenas uma das muitas situações vistas nos 27 casos, que vislumbraram também cartas em que o valor pago pelas alforrias foi superior ao preço médio descrito nos inventários - como o caso da pequena Catarina, de 11 meses, alforriada pela quantia de Rs. 300\$000, sendo o preço médio das cativas nessa faixa etária, segundo inventários, calculado em torno de Rs. $134 \$ 000--^{10}$ cartas em que o valor das alforrias aproxima-se do preço médio segundo os inventários, etc. Ou seja, não foi possível verificar um padrão, talvez por ser um universo tão pequeno.

Para os alforriados do sexo masculino, o número de casos é ainda menor: 19 ocorrências que permitiriam a comparação entre o valor das alforrias e preço médio descrito nos inventários, segundo o ano de registro e a idade do escravo. Também para eles constatamos que o valor pago pela liberdade foi menor que os preços médios calculados segundo a avaliação dos inventários. Valendo-nos do argumento de Kátia Mattoso, para quem o preço mais baixo das alforrias das mulheres fez-se pela proximidade e intimidade com os senhores, poderíamos sugerir que também os homens teriam a possibilidade de negociação para reduzir os valores da alforria. Dentro desta pequena amostragem, não houve nenhum caso onde o valor das alforrias fosse maior que o preço médio averiguado nos inventários. Com a constância verificada entre os homens, ficamos mais perto de um possível modelo em que a tendência das alforrias, em ambos os sexos, era subvalorizar os cativos.

Peter Eisenberg, buscando explicar a superioridade das mulheres entre os alforriados de Campinas, menciona seus preços mais baixos em relação aos homens, além do fato de a mulher escrava possuir mais oportunidades para estabelecer laços afetivos com seus senhores. Todavia, o pesquisador sugeriu ainda uma terceira hipótese para a compreensão deste aspecto e que estaria ancorada nas "circunstâncias especiais da família escrava". Já que o filho seguia a condição legal da mãe estipulada pelo partus sequitur ventrem, "a própria família escrava deveria ponderar sobre a importância de salvar da escravidão os futuros irmãos, filhos e netos, através da alforria das escravas" (Eisenberg, 1987, p. 184).

${ }^{10}$ Arquivo da CSM, II ofício, livro de notas número 17 (1863-1867), folha.10. 
Enidelce Bertin, constatando a superioridade das mulheres nas alforrias de São Paulo, também destaca, entre outros fatores - como menor preço das cativas, maior aproximação com seus senhores e maiores oportunidades em acumular pecúlio -, a liberdade concedida em retribuição às "crias geradas". Segundo a autora,

para que as alforrias das mães escravas conferissem vantagem para os proprietários, estes deveriam continuar escravizando os filhos delas depois de libertá-las, o que ocorreria se estes já não fossem mais crianças - em função do direito romano de o filho acompanhar a condição da mãe. Se o senhor justificava a liberdade da escrava pelos novos escravos "dados" por ela, podemos inferir que os filhos já estão crescidos, portanto podem ser separados da mãe. Portanto, para o proprietário, a alforria é prêmio à escrava que lhe deu outros escravos. Ainda que seus filhos continuassem escravos, estava colocada uma possibilidade para que a mãe, agora liberta, viesse resgatá-los da escravidão futuramente. (Bertin, 2004, p.141)

Também encontramos, em Mariana, sete cartas que justificavam as alforrias das escravas pelas crias que produziram. Este foi o caso da escrava Bárbara que, no ano de 1845, recebeu a carta de alforria das mãos da senhora Antônia Maria de Jesus. Dizia o registro que, depois de a senhora receber 400 mil réis "e em atenção a dita escrava já ter nos dado sete crias", a escrava Bárbara gozaria da liberdade como se nascesse de ventre livre. ${ }^{11}$ A escrava Maria do Carmo, que tinha entre 30 e 40 anos de idade, obteve a carta de alforria no ano de 1847 das mãos da senhora Ana Joaquina Gomes com a condição de servir a esta enquanto fosse viva "pelos bons serviços que me tem prestado bem como pela produção de filhos". ${ }^{12}$ A escrava Francisca, de 50 anos, pertencente ao senhor Joaquim Inácio de Ramos e sua mulher Manuela Joaquina do Espírito Santo, foi alforriada no ano de 1870 "sem cláusula ou condição alguma por nos ter dado crias e por isso queremos que este nosso escrito lhe sirva de prova". ${ }^{13}$ A escrava Antônia pertencente ao senhor Joaquim Antônio Gomes recebeu,

11 Arquivo da CSM, I ofício, livro de notas número 112 (1844-1850), folha 49.

12 Arquivo da CSM, I ofício, livro de notas número 112 (1844-1850), folha 33v.

13 Arquivo da CSM, I ofício, livro de notas número 120 (1867-1872), folha 58. 
no ano de 1857, carta de alforria "por ter a mesma gerado muitas crias". ${ }^{14}$ Bárbara, escrava de Manuel Ignácio de Mello e Souza, conhecido como Barão do Pontal, foi alforriada depois de criar cinco filhos. Dizia a carta que

Bárbara crioula, filha de Íria e neta de Domingos e Joana de Ramos atendendo aos serviços que tem prestado e ao cuidado e tratamento que tem empregado na criação de cinco filhos que vivem sendo o último maior de seis anos, a saber: Isabel, Justina, Florêncio, Vicente e Cláudio gozará de hoje em diante da liberdade como se nascesse de ventre livre e poderá residir nesta ou outra minha casa enquanto me agradar o seu serviço e ela quiser, fazendo qualquer serviço de casa ou da roça como tem até o presente e recebendo a porção de 14 mil réis anuais e quando ela queira retirar-se de minha casa e fazenda receberá mais 20 mil réis para seus arranjos. E para que conste $e$ ninguém estorve este benefício que lhe faço gratuitamente passo o presente. ${ }^{15}$

Pelo inventário do dito Barão ficamos sabendo que a alforria de escravas com mais de cinco filhos criados era prática ordinária em suas propriedades. Segundo a declaração exposta no inventário, tal prática constituía de uma política que visava

evitar-se nas minhas fazendas os desatinos que se dizem verificados [ilegível] escravas ignorantes e perversas no tempo da gravidez e do parto e da reação [ilegível] dos filhos nos primeiros anos concede às minhas escravas quando estivesse criando seus filhos alguma exceção de serviços mais penosos e lhes prometi a liberdade as que criasse cinco filhos e estivessem vivos, quando o quinto filho chegasse à idade de seis anos e tendo [ilegivel], mas o pai se fosse casado com [a mãe] seria forro; cumpri a primeira parte da minha promessa a respeito de Graciana crioula e Maria da Conceição parda (...). ${ }^{16}$

14 Arquivo da CSM, II ofício, livro de notas número 14 (1851-1855), folha 54v.

15 Arquivo da CSM, II ofício, livro de notas número 14 (1851-1855), folha 34v.

16 Rezende, 2008, p. 142. O Código Filipino estabelecia o benefício da alforria para as escravas que concebessem e criassem um número igual ou superior a sete filhos (Mattoso, 1990). 
Em situações como esta, dificilmente as mães (e, quando era o caso, também os pais) aforradas deixariam a propriedade onde foram escravas. Além do fato de, em geral, não ter relações sociais ou familiares que as abrigassem alhures, ainda estariam, por afeto, ligadas ao local onde residiam seus filhos.

Algumas cartas enfatizavam que a liberdade concedida às mães não alcançava seus filhos. Maria africana, pertencente a Manuel Gonçalves da Cunha, teve, em 1843, sua carta registrada, "ficando os seus filhos pequenos sujeitos ao cativeiro; querendo o pai ou a mãe tirá-los, ficam com o preço de 300 mil réis cada um, sendo uma de nome Maria e outra de nome Ana". ${ }^{17}$ No caso da escrava Maria Vitória, seus filhos - José, Josefa, Germana, Felisberta, Maria, Honório e Patrício - também foram manumitidos pela senhora Ana Joaquina de Araújo, no ano de 1849, "em atenção aos bons serviços por eles prestados e por mim recebidos" com a condição de servir à senhora enquanto esta vivesse. ${ }^{18}$

Tabela 6 - Escravos alforriados segundo gênero e idade (Mariana - 1840-1888)

\begin{tabular}{ccccccc}
\hline Faixa etária & \multicolumn{2}{c}{ Homens } & \multicolumn{2}{c}{ Mulheres } & \multicolumn{2}{c}{ Total } \\
\cline { 2 - 7 } & $\boldsymbol{n}$ & $\%$ & $\boldsymbol{n}$ & $\%$ & $\boldsymbol{N}$ & $\%$ \\
\hline $0-14$ & 30 & 13,8 & 31 & 14,2 & 61 & 28,0 \\
\hline $15-29$ & 26 & 11,9 & 28 & 12,8 & 53 & 24,7 \\
\hline $30-44$ & 22 & 10,1 & 35 & 16,1 & 57 & 26,2 \\
\hline $45-59$ & 10 & 4,6 & 14 & 6,4 & 24 & 11,0 \\
\hline Mais de 59 anos & 12 & 5,5 & 10 & 4,6 & 22 & 10,1 \\
\hline Total & 100 & $\mathbf{4 5 , 9}$ & $\mathbf{1 1 8}$ & $\mathbf{5 4 , 1}$ & $\mathbf{2 1 8}$ & $\mathbf{1 0 0}$ \\
\hline
\end{tabular}

Nem todas as cartas informavam acerca da idade dos alforriados. Dos 569 escravos registrados nas cartas, apenas 218 tiveram suas idades mencionadas, o que corresponde a 38,3\%. Deste universo, $28,0 \%$ referiam-se a crianças. ${ }^{19} \mathrm{~A}$ alta porcentagem de crianças beneficiadas

\footnotetext{
17 Arquivo da CSM, I ofício, livro de notas número 112 (1844-1850), folha 30.

${ }^{18}$ Arquivo da CSM, I ofício, livro de notas número 113 (1850-1854), folha 3.

${ }^{19}$ De acordo com a análise realizada por Eisenberg, as faixas etárias dos muito jovens (até 10 anos) e dos mais velhos (acima dos 49 anos) foram favorecidas com a concessão das alforrias. Segundo o autor, "a determinação econômica leva em conta a alta probabilidade de que os escravos muito jovens e os muito velhos prestassem menos para o trabalho físico duro. Como eram trabalhadores menos produtivos, ou até dependentes, os preços destes indivíduos eram baixos, o que facilitou a compra da alforria e também minimizou a perda de capital sofrida pelo senhor por causa da alforria. No caso dos velhos, além de terem preços baixos, estes tiveram muitos anos para acumular um pecúlio" (Eisenberg, 1987, p.191).
} 
com a carta de alforria deve-se a sua boa representação na população total. Constatamos que $27,5 \%$ eram compostos por crianças, porcentagem um pouco inferior à calculada para as mulheres, que foi de 29,9\%. Além do alto índice de crianças alforriadas, chama-nos a atenção também o fato de mais da metade das mulheres alforriadas estar em idade considerada de maior produtividade, enquanto que, entre os homens, idosos e crianças eram os mais contemplados. Vale a ressalva: sendo o número de escravos alforriados com idades descritas relativamente pequeno, causaria indesejáveis distorções fazer uma análise dividida em décadas.

Examinando as alforrias para o Rio de Janeiro das primeiras três décadas do século XIX, período de intensa entrada de escravos africanos na cidade, Mary Karasch encontrou, de um universo de 1.319 cartas, apenas 176 destinadas às crianças, o que correspondeu a $13 \%$ da amostra (Karasch, 2000, p.455). A autora atribuiu a pequena participação dos infantes na população alforriada a sua baixa participação na população cativa total do Rio de Janeiro. Karasch destaca a afeição como justificativa mais presente nos registros protagonizados por crianças.

De modo geral, a explicação mais comum para a alforria de crianças era o fato de serem crias. "Cria da casa" ou "amor de criação" era frequentemente a única explicação dada ou necessária para uma determinada alforria; mas alguns senhores, ao libertar sua cria, entravam em pormenores, declarando seu amor e afeição pela criança - "por causa do muito amor, porque ele é minha cria" ou por causa da "afeição cordial que ela tem pelo negrinho, pois ele é sua cria". Essas expressões de amor em relação às crias documentam os laços familiares e de amizade que levavam seus donos a dar-lhes a liberdade. (Karasch, 2000, p.457)

Observando os papéis de liberdade para crianças escravas em Mariana, vimos muitos casos com justificativas como o "amor por tê-lo criado" ou "pelo amor que tenho adquirido" ou "pelo grande amor e parentesco espiritual". Das 61 crianças alforriadas, 12 tiveram como fundamento o "amor" ou a "afeição". O pequeno Justo, de 6 anos, foi uma dessas crianças beneficiadas. Segundo seu proprie- 
tário, o Barão do Itabira, que registrou a carta em 1855, a liberdade seria concedida sem ônus algum "ao meu cabritinho Justo, de idade de 6 anos, só por amor de sua criação". ${ }^{20}$ Em outras cartas, mesmo apelando-se ao amor, cabia à criança alforriada alguma condição. Matheus, de 8 anos, foi aforrado pela senhora Caetana Pulchéria da Encarnação, no ano de 1848, devido à grande afeição e ao fato de a senhora tê-lo criado como filho, com a condição, segundo palavras da autora, "de acompanhar-me, enquanto viva for, na condição de escravo". ${ }^{21}$ A menina Sebastiana, de 7 anos, foi dita forra "pelo muito amor de criar em nossos braços", no ano de 1848 pelo casal Joaquim Severino da Costa e sua mulher Ana Joaquina da Encarnação com uma obrigação a cumprir: "ficará gozando de sua liberdade como se de ventre livre nascesse com a condição, porém, de nos acompanhar e nos servir enquanto vivos formos". 22

Em outras ocasiões, a condição era o pagamento em dinheiro. Para libertar Sebastiana, de 4 anos e 4 meses, o exigido pela proprietária, Joana Correia Leal, foi o pagamento de Rs 500\$000. A carta, registrada em 1856, mencionava que a quantia fora paga pelo senhor Clementino Gonçalves Leal. ${ }^{23}$ Perciliana, de 2 anos, escrava de José Thomas de Carvalho, recebeu a alforria depois do pagamento de Rs $200 \$ 000$. Mesmo após a quitação, a carta, registrada em 1869, mencionava que a menina deveria ficar em companhia do proprietário até "a idade de emancipação se antes não efetivar bom casamento". ${ }^{24}$

Em três cartas, as crianças alforriadas haviam nascido após a Lei do Ventre Livre. Nesses casos, as crianças foram descritas como ingênuas e os senhores enfatizavam que cediam o direito que tinham nos seus serviços. Em duas ocasiões, os senhores receberam pagamento em dinheiro em troca da carta de liberdade concedida aos ingênuos. Nessas duas ocasiões, as quantias determinadas foram fornecidas pelos padrinhos.

Metade das cartas de alforria, 50,9\%, foi concedida a escravos que tinham entre 15 e 44 anos (Tabela 6). Entre as razões para a maioria das alforrias serem concedidas nessa faixa etária está a superioridade numérica desse grupo na população mancípia - segundo dados obti-

${ }^{20}$ Arquivo da CSM, II ofício, livro de notas número 114 (1851-1855), folha 14v.

21 Arquivo da CSM, II ofício, livro de notas número 112 (1851-1855), folha 58v-p.59.

22 Arquivo da CSM, II ofício, livro de notas número 114 (1851-1855), folhas 90v-p.91.

23 Arquivo da CSM, II ofício, livro de notas número 117 (1854-1857), folhas 67v-p.68.

24 Arquivo da CSM, II ofício, livro de notas número 120 (1867-1872), folhas 32-p.32v. 
dos através de inventários post-mortem para o período 1840-1888, os escravos entre 15 e 44 anos correspondiam a 46,2\% do total. É nessa faixa que ocorria o maior desequilíbrio entre homens e mulheres beneficiados com a carta de alforria. Calculando a razão entre os sexos entre os alforriados, vimos que na faixa etária correspondente às crianças, a razão entre os sexos foi de 97 , já para os escravos na faixa etária 15-50 anos, essa razão foi de 76, demonstrando a predominância das mulheres entre os alforriados de mesmo grupo de idade. Entre os escravos com mais de 50 anos, o equilíbrio é novamente observado. A razão entre os sexos nessa faixa foi de 93.

A Tabela 6 indica ainda que 21,1\% das alforrias referiam-se a escravos com mais de 44 anos. Percentual considerável, pois era nessa faixa etária que estava a minoria da população cativa. Considerando a amostragem obtida através dos inventários, encontramos 15,4\% dos escravos com mais de 44 anos no período 1840-1888. Analisando as justificativas para a alforria de escravos com idade superior aos 44 anos, vimos muitas cartas alegando retribuição aos serviços prestados ao longo da vida. Delfina, de 60 anos, escrava de dona Tereza Marcelina, de São Joaquim, teve sua alforria registrada em 1853, sem ônus algum, "em atenção ao seu bom procedimento e serviços prestados". ${ }^{25}$ Elias, de 70 anos, recebeu carta no ano de 1855 sem nenhuma condição, das mãos do Barão de Itabira em retribuição aos bons serviços prestados. ${ }^{26}$ José, descrito como velho, escravo de dona Ana Ferreira Gomes, recebeu sua carta de alforria no ano de 1880, "em razão de sua fidelidade e amor com que me criou e bons serviços que me tem prestado", com a condição de servir a sua senhora enquanto for viva. ${ }^{27}$ Alguns documentos justificavam a alforria pela idade avançada e saúde debilitada. A escrava Brígida, idosa, foi feita forra no ano de 1855 pelo Barão de Itabira "pelo preço de duzentos mil reis em razão da sua avançada idade e crônicas enfermidades que padece". ${ }^{28}$ Para o final do período escravista, encontramos cartas que alforriavam escravos idosos baseadas na lei de 1885 . Os sexagenários Luiz, Francisca, Josefa, Teresa Grande e Teresa, pertencentes ao coronel João Mariano Rodrigues Teixeira Pereira tiveram a alforria decretada em decorrência da lei de 1885.

\footnotetext{
${ }^{25}$ Arquivo da CSM, II ofício, livro de notas número 12 (1851-1855), folha 52.

${ }^{26}$ Arquivo da CSM, II ofício, livro de notas número 14 (1851-1855), folha 43v.

${ }^{27}$ Arquivo da CSM, II ofício, livro de notas número 22 (1872-1883), folha 28v.

${ }^{28}$ Arquivo da CSM, I ofício, livro de notas número 117 (1854-1857), folha 25-p.25v.
} 
Tabela 7 - Escravos alforriados segundo gênero e origem (Mariana - 1840-1888)

\begin{tabular}{c|c|c|c|c|c}
\hline \multicolumn{3}{c|}{ Origem } \\
\hline Africanos & \multicolumn{2}{c}{ Crioulos } & Não identificados \\
\hline Homens & Mulheres & Homens & Mulheres & Homens & Mulheres \\
\hline $41(7,2 \%)$ & $29(5,1 \%)$ & $162(28,5 \%)$ & $192(33,7 \%)$ & $61(10,7 \%)$ & $84(14,8 \%)$ \\
\hline \multicolumn{3}{c|}{$354(62,2 \%)$} & \multirow{2}{*}{$145(25,5 \%)$} \\
\hline \multicolumn{3}{c}{$50(12,3 \%)$} & $564(74,5 \%)$ & $(100 \%)$ \\
\hline \multicolumn{6}{c}{}
\end{tabular}

Para 424 alforriados, conseguimos informações acerca da origem. Conforme vemos na Tabela 7, a predominância foi dos crioulos, com $62,2 \%$ do total de escravos alforriados, enquanto os africanos representavam $12,3 \%$. Estas porcentagens são próximas às da amostragem de escravos obtida pelos inventários post-mortem para o período $1840-1888$, na qual 16,3\% do contingente cativo eram de africanos expressamente identificados e 64,6\% eram crioulos.

Tabela 8 - Escravos alforriados segundo sexo e origem por década (Mariana 1840-1888)

\begin{tabular}{|c|c|c|c|c|c|c|c|}
\hline \multirow{3}{*}{ Décadas } & \multicolumn{7}{|c|}{ Origem } \\
\hline & \multicolumn{2}{|c|}{ Africanos } & \multicolumn{2}{|c|}{ Crioulos } & \multicolumn{2}{|c|}{ Não identificados } & \multirow[t]{2}{*}{ Total } \\
\hline & Homens & Mulheres & Homens & Mulheres & Homens & Mulheres & \\
\hline \multirow{2}{*}{$1840-1849$} & $9(8,3 \%)$ & $7(6,5 \%)$ & $38(35,2 \%)$ & $41(38,0 \%)$ & $3(2,8 \%)$ & $10(9, \%)$ & \multirow{2}{*}{$108(100 \%)$} \\
\hline & \multicolumn{2}{|c|}{$16(14,8 \%)$} & \multicolumn{2}{|c|}{$79(73,2 \%)$} & \multicolumn{2}{|c|}{$13(12,0 \%)$} & \\
\hline \multirow{2}{*}{$1850-1859$} & $13(7,3 \%)$ & $9(5,1 \%)$ & $51(28,8 \%)$ & $67(37,9 \%)$ & $16(9,0 \%)$ & $21(11,9 \%)$ & \multirow[t]{2}{*}{$177(100 \%)$} \\
\hline & \multicolumn{2}{|c|}{$22(12,4 \%)$} & \multicolumn{2}{|c|}{$118(66,7 \%)$} & \multicolumn{2}{|c|}{$37(20,9 \%)$} & \\
\hline \multirow{2}{*}{$1860-1869$} & $10(9,5 \%)$ & $4(3,8 \%)$ & $26(24,8 \%)$ & $37(35,2 \%)$ & $13(12,4 \%)$ & $15(14,3)$ & \multirow[t]{2}{*}{$105(100 \%)$} \\
\hline & \multicolumn{2}{|c|}{$14(13,3 \%)$} & \multicolumn{2}{|c|}{$63(60,0 \%)$} & \multicolumn{2}{|c|}{$28(26,7 \%)$} & \\
\hline \multirow{2}{*}{$1870-1879$} & $8(7,9 \%)$ & $2(2,0 \%)$ & $30(29,7 \%)$ & $32(31,7 \%)$ & $13(12,9 \%)$ & $16(15,8 \%)$ & \multirow[t]{2}{*}{$101(100 \%)$} \\
\hline & \multicolumn{2}{|c|}{$10(9,9 \%)$} & \multicolumn{2}{|c|}{$62(61,4 \%)$} & \multicolumn{2}{|c|}{$29(28,7 \%)$} & \\
\hline \multirow{2}{*}{$1880-1888$} & $1(1,3 \%)$ & $7(9,0 \%)$ & $18(23,1 \%)$ & $14(17,9 \%)$ & $16(20,5 \%)$ & $22(28,2 \%)$ & \multirow[t]{2}{*}{$78(100 \%)$} \\
\hline & \multicolumn{2}{|c|}{$8(10,3 \%)$} & \multicolumn{2}{|c|}{$32(41,0 \%)$} & \multicolumn{2}{|c|}{$38(48,7 \%)$} & \\
\hline \multirow{2}{*}{ Total } & $41(7,2 \%)$ & $29(5,1 \%)$ & $163(28,6 \%)$ & $191(33,6 \%)$ & $61(10,7 \%)$ & $84(14,8 \%)$ & \multirow[t]{2}{*}{$569(100 \%)$} \\
\hline & \multicolumn{2}{|c|}{$70(12,3 \%)$} & \multicolumn{2}{|c|}{$354(62,2 \%)$} & \multicolumn{2}{|c|}{$145(25,5 \%)$} & \\
\hline
\end{tabular}

De 1840-1849 para 1880-1888, o percentual de alforriados sem informação cresce, gradativa e continuamente, de $12 \%$ para $48,7 \%$, causando uma óbvia deformação que faz com ambas as colunas da tabela (africanos e crioulos) percam em representatividade ao longo 
do tempo. Considerando a proibição do tráfico em 1850, a geração exclusivamente de crioulos na reprodução endógena e o fato de que não fazia sentido algum o senhor temer a acusação de injusto cativeiro na confecção de uma carta de alforria, é bastante plausível que a participação dos crioulos entre os de origem não identificada fosse largamente maior que a dos africanos.

De acordo com o levantamento realizado pelos inventários post-mortem, os crioulos sempre foram maioria absoluta, e cresciam em participação à medida que as décadas avançavam: eram $55,6 \%$ da população cativa nos anos $1840 ; 61,2 \%$ na década de $1850 ; 62,2 \%$ na década de 1860; 77,7\% na década de 1870; e 80,9\% nos anos 1880 . Entre os alforriados, os crioulos oscilaram bastante, mas sempre atrelados às variações, já citadas, dos de origem não identificada. Em contrapartida, os africanos diminuíam sua participação na população cativa durante o período 1840 -1888: eram $28,6 \%$ da população cativa nos anos 1840; 15,0\%, nos anos 1850; 14,6\%, nos anos 1860; 6,4\%, nos anos 1870; e 5,1\%, na década de 1880 . Entretanto, o comportamento estatístico entre eles, quando alforriados, não foi de simples declínio de participação, mas de pequenas oscilações culminando em queda mais significativa nos anos 1870 e tornando a subir moderadamente nos 1880 .

Ainda sobre as Tabelas 7 e 8 , quando analisamos as alforrias segundo a origem e o sexo, africanos e crioulos tiveram comportamentos diversos. Entre os africanos, os homens foram maioria nos registros: conquistaram 41 cartas de liberdade e as mulheres, 29. A menor representatividade das mulheres entre os alforriados africanos deve-se à sua pequena participação na população total. Observando a descrição dos escravos nos inventários post-mortem arrolados no período 1840-1888, apenas 220 eram mulheres africanas. Ou seja, dos 5.266 escravos levantados, as mulheres africanas correspondiam a $4,2 \%$, enquanto os africanos representavam $12,1 \% .{ }^{29}$ Considerando todo o período (1840-1888), na amostragem dos inventários, havia 2,9 homens para cada mulher entre os africanos; já entre os africanos alforriados, a proporção reduz-se à metade: 1,4 homem para cada mulher. As cartas concedidas aos crioulos foram orientadas majorita-

${ }^{29}$ A maioria dos escravos do sexo masculino entre a população africana resulta da preferência pelos homens no tráfico internacional de escravos. Sabe-se, pela historiografia, que, dos cativos desembarcados nos portos brasileiros, a proporção era de três homens para cada mulher (Schwartz, 1988; Klein, 1989; Luna \& Klein, 2000, Marquese, 2006). 
riamente a mulheres $(0,85$ homem para cada mulher $)$, embora estas fossem minoria na população total ( 1,11 homem para cada mulher).

É possível afirmar, que, para Mariana, de maneira proporcional, a mulher cativa, qualquer que fosse sua origem, tinha maior probabilidade de receber a carta de alforria. Observando as alforrias segundo a origem e a idade, vimos entre os africanos a predominância dos mais velhos. Dos africanos libertados, 25 tiveram a idade mencionada: apenas duas escravas tinham menos de 29 anos (Maria, de nação Benguela, tinha entre 16 e os 18 anos, e Carlota, com 27 anos); oito possuíam idades entre 30 e 44 anos; e 15 eram maiores que 44 anos. Para os crioulos, a idade foi mencionada para 193 alforriados: 61 tinham até 14 anos; 52 estavam na faixa 15-29 anos; 49, na faixa 30-44 anos; e 31 tinham mais de 44 anos. O comportamento das alforrias, de acordo com a idade, difere para africanos e crioulos. Enquanto para os primeiros as alforrias crescem conforme aumentam em idade, para os crioulos, a possibilidade de liberdade diminui à medida que os escravos tornam-se mais velhos. Andrea Lisly Gonçalves, analisando as alforrias para a Comarca de Ouro Preto no período de 1808 a 1870, afirma que o fato de os africanos alcançarem a alforria em idade mais avançada que os crioulos decorre "muito provavelmente em função do tempo de ressocialização necessário para que se tornassem escravos ladinos e, portanto, mais aptos a pressionar com êxito pela obtenção de sua alforria" (Gonçalves, 2011, p.189).

Ainda buscando o perfil do alforriado, embora a grande maioria fosse crioula, apenas 138 contavam com a filiação registrada nas cartas $(24,2 \%$ do total de escravos libertos). Destes, 14 tiveram pai e mãe relacionados; os demais apresentavam apenas o nome da mãe.

Encontramos 39 grupos familiares sendo beneficiados com a alforria no total das 425 cartas. Foram 113 forros inseridos em famílias, o que correspondia a $19,9 \%$ do total dos contemplados com o papel de liberdade. ${ }^{30}$ Possivelmente, houve subdescrição com relação ao parentesco dos manumissos. Muitas cartas concedendo liberdade a mais de um escravo poderiam tratar de escravos aparentados, porém, sem informações expressas nos registros, não há como sustentar uma afirmativa. Em um caso conseguimos sanar a ausência

${ }^{30}$ Ao examinar os vínculos familiares para o período 1850-1888, deparamo-nos com a porcentagem de 36,3\% dos escravos inseridos em famílias (Teixeira, 2001, p.107). 
de detalhamento através do cruzamento da carta de alforria com uma ação de liberdade. Ambas as fontes referiam-se a 11 escravos pertencentes a Antônio Fernandes Barroso. Pela carta, registrada em 1874, conhecemos apenas nome e sobrenome dos escravos envolvidos: Antônia Pires, Ana Pires, Isabel Pires, Rita Pires, Juventina Pires, Faustino Pires, José Pires, Clemente, João Pires, Mariana Pires e Miguel Pires. ${ }^{31}$

A referência ao sobrenome Pires para quase todos os alforriados da propriedade do senhor Antônio Fernandes Barroso sugere o vínculo familiar entre os alforriados, entretanto, não podíamos afirmar apenas com essa informação que os escravos em questão fossem pertencentes à mesma família. Embora não fosse comum, poderia ser um caso de sobrenome fornecido pelo senhor a toda sua escravaria. A dúvida foi desfeita quando tomamos conhecimento da ação de liberdade aberta pela escrava Antônia Pires, também no ano de 1874, que pretendia libertar-se e a sua família do injusto cativeiro em que viviam. Assim, pudemos verificar que aquele grupo correspondia a uma família de três gerações de cativeiro.

Quadro 1 - Família de Antônia Pires

\begin{tabular}{|c|c|c|c|c|c|c|c|c|}
\hline \multicolumn{7}{|c|}{$\begin{array}{c}\text { Antônia Pires } \\
\text { (48 anos) }\end{array}$} & $\begin{array}{l}\text { Miguel } \\
\text { Pires } \\
(50 \text { anos })\end{array}$ & $\begin{array}{r}\text { Mariana Pires } \\
\quad(30 \text { anos })\end{array}$ \\
\hline \multicolumn{3}{|c|}{$\begin{array}{l}\text { Ana Pires } \\
\text { (28 anos) }\end{array}$} & $\begin{array}{c}\text { Isabel } \\
\text { Pires } \\
\text { (25 anos) }\end{array}$ & $\begin{array}{l}\text { Faustino } \\
\text { Pires } \\
\text { (20 anos) }\end{array}$ & $\begin{array}{l}\text { Rita Pires } \\
\text { (14 anos) }\end{array}$ & \begin{tabular}{|c|} 
Juventina \\
Pires \\
(12 anos)
\end{tabular} & & \\
\hline $\begin{array}{c}\text { José } \\
\text { Pires } \\
\text { (14 anos) }\end{array}$ & $\begin{array}{l}\text { Clemente } \\
\text { (12 anos) }\end{array}$ & $\begin{array}{c}\text { João } \\
\text { Pires } \\
\text { (9 anos) }\end{array}$ & & & & & & \\
\hline
\end{tabular}

Antônia Pires foi escrava de Antônio Fernandes Barroso, e seus filhos e netos nasceram naquela propriedade e ali viveram até o falecimento do senhor em 1857. Segundo a história narrada por Antônia Pires, Antônio Fernandes Barroso, em vida, declarou verbalmente, em presença de muitas pessoas, que, após sua morte, a família de Antônia Pires ficaria livre. Entretanto, os herdeiros do senhor Barroso, desconsiderando a promessa e julgando-se no direito aos suplicantes, tentaram chamá-los ao cativeiro. Buscando defender a liberdade, Antônia Pires recorre à Justiça. Baseando-se na lei de 1871, o defensor de Antônia Pires argumentou que

31 Arquivo da CSM, Carta de alforria, I Ofício, Livro de Notas, 122 (1873-1875), folha 62. 
estão os suplicantes forros ou livres por força das determinações positivas do artigo $8^{\circ}$, parágrafo $2^{\circ}$ da lei número 2040 de 28 de setembro de 1871, decreto número 4.835 de $1^{\circ}$ de dezembro de 1872; porquanto, todas essas leis e regulamentos conferem a liberdade aos escravos que não tiverem sido matriculados nas coletorias dos municípios de suas residências até o dia 30 de setembro de 1873. Pela certidão junto provam os suplicantes que não se acham matriculados como escravos. Assim pois são livres por força das leis citadas. ${ }^{32}$

De fato, não havia registro da matrícula de nenhum dos membros da família de Antônia Pires, e, com base nesse fato, a jurisprudência foi favorável à liberdade dos suplicantes,

em vista do artigo $8^{\circ}$, parágrafo $2^{\circ}$ da lei de 28 de setembro de 1871 e decreto de $1^{\circ}$ de dezembro de 1871, e tendo em vista a certidão negativa a folhas $5 v, 6$ e $6 v$ considero libertos os escravos Antônia Pires, Ana Pires, Isabel, Rita Pires, Juventina Pires, Faustino Pires, José Pires, Clemente Pires, João Pires, Mariana Pires, Miguel Pires, assim julgado, mando que se lhes dê a certidão desta para valer como carta de liberdade de que terão pleno gozo. Mariana, 23 de junho de 1874.33

Neste mesmo ano, foi passada a carta de alforria aos membros da família de Antônia Pires.

Tabela 9 - Famílias escravas beneficiadas com a concessão da carta de alforria (Mariana - 1840-1888)

\begin{tabular}{ccccc}
\hline \multicolumn{5}{c}{ Tipos de Família } \\
\hline Casal & Casal e filhos & Mãe e filhos & Irmãos & Total \\
\hline 6 & 4 & 23 & 6 & 39 \\
\hline
\end{tabular}

\footnotetext{
${ }^{32}$ Arquivo da CSM, Ação de Liberdade, I ofício, códice 404, auto 8839, folha 2v.

${ }^{33}$ Arquivo da CSM, Ação de Liberdade, I ofício, códice 404, auto 8839, folha 6.
} 
A Tabela 9 mostra a grande predominância das famílias formadas por mães e filhos, sendo a maioria composta por mãe com um ou dois filhos (Tabela 10). Somente em cinco situações as cartas referiamse a mães escravas com uma prole superior a quatro filhos. Maria Vitória, escrava da senhora Ana Joaquina de Araújo foi alforriada no ano de 1849, juntamente com os seus sete filhos "em atenção aos bons serviços por eles prestados e por mim recebidos ou cumpridos e por recomendação do meu falecido marido, deixo-os livres somente com a condição de prestar-me serviços até o meu falecimento". ${ }^{34}$

Associando as informações das Tabelas 9 e 10, observam-se dez casais alforriados pelas cartas de liberdade: seis sem nenhuma menção à prole; um com dois filhos; dois com três descendentes; e, por fim, um com seus quatro filhos. Entre os casais com filhos, estava a família de Paulo africano, 38 anos, e Carlota africana, 27 anos, e seus rebentos Manuel e Antônio, ambos de 6 anos, e Cornélio, de 2, todos pertencentes ao casal Francisco Marcelino Almeida Freitas e sua mulher, dona Maria Rosa de Jesus, alforriados no ano de 1844 "com a condição de me servirem e a minha mulher até que consigamos pagar as nossas dívidas contraídas até a data desta". ${ }^{35}$

Em seis cartas, havia a alforria de famílias compostas apenas por irmãos. Para cinco destes casos, foi mencionada apenas a filiação materna; e, em um caso, pai e mãe foram referidos. Não temos informações suficientes para dizer qual o destino dos progenitores dessas famílias de irmãos, mas é provável que já estivessem libertos ou falecidos.

Tabela 10 - Número de filhos das famílias alforriadas (Mariana- 1840-1888)

\begin{tabular}{cccccccc}
\hline \multirow{2}{*}{ Tipos de família } & \multicolumn{7}{c}{ Número de filhos } \\
\cline { 2 - 9 } & $\mathbf{1}$ & $\mathbf{2}$ & $\mathbf{3}$ & $\mathbf{4}$ & $\mathbf{5}$ & $\mathbf{6}$ & $\mathbf{7}$ \\
\hline Casal com filhos & - & 1 & 2 & 1 & - & - & - \\
\hline Mãe com filhos & 10 & 8 & - & - & 3 & 1 & 1 \\
\hline
\end{tabular}

Muitos estudos relativos à alforria concluíram que a família escrava, além de papel de destaque na experiência diária de resistência à escravidão, teve uma função importante no percurso que levava à liberdade. Tarcísio Botelho, pesquisando as manumissões em Montes

34 Arquivo da CSM, Carta de alforria, I Ofício, Livro de Notas, 113 (1850-1854), folha 3.

35 Arquivo da CSM, Carta de alforria, I Ofício, Livro de Notas, 118 (1864-1868), folhas 114v-115. 
Claros, norte de Minas Gerais, acerca do século XIX, percebeu que muitas das alforrias eram resultado de lutas desses grupos familiares. De acordo com o autor,

estas lutas pela liberdade reforçavam ainda mais os laços familiares. Vemos escravos que lutam não apenas por si, mas também por seus irmãos e outros parentes, reafirmando a importância da família para o cativo. O apoio mútuo permitido por ela reanimava o empenho em sobreviver dentro da escravidão e abria esperanças por um futuro de liberdade. (Botelho, 1996)

Isabel Cristina Ferreira dos Reis, estudando o tema das alforrias para a Bahia do século XIX, concluiu que a família escrava foi de importância fundamental na consecução do projeto de liberdade dos escravizados, pois

para o escravo que tinha laços familiares, não bastava a liberdade individual. Ele buscava, persistentemente e das formas mais variadas, por meios legais, ilícitos ou até desesperados, livrar a si e aos seus familiares do cativeiro. (Reis, 2001, p. 111)

Encontramos em Mariana muitas ações de liberdade envolvendo famílias escravas que se julgavam em injusto cativeiro. Prática comum em todo o período escravista, essas batalhas judiciais intensificaramse durante as últimas décadas - especialmente após a lei de 1871, quando a legislação passou a interferir na relação senhor/escravo e ainda garantiu aos cativos o direito à acumulação ao pecúlio e a possibilidade de serem alforriados pelo Fundo de Emancipação. Acima, vimos o exemplo da família de Antônia Pires, mas dezenas de outras histórias poderiam ser contadas para demonstrar a importância da parentela na luta pela liberdade (Teixeira, 2008).

Kátia Lorena Novais Almeida, estudando as alforrias para Rio de Contas, região baiana caracterizada pela produção voltada para o mercado regional, também percebeu as relações familiares entre 
os escravos como um incentivo importante para o acesso à alforria, principalmente quando conquistada mediante pagamentos de quantias em dinheiro. Conforme demonstra a documentação - cartas de alforria, testamentos, registros de batismos, inventários post-mortem, ações de liberdade, etc -, muitos contavam com o auxílio de familiares para angariar fundos para a conquista da liberdade (Almeida, 2006).

No que diz respeito às cartas de alforria compradas em Juiz de Fora, Antônio Henrique Lacerda conseguiu encontrar dez compras realizadas por familiares do liberto. Consoante o autor,

as cartas compradas por familiares do alforriado somaram dez registros. Em quatro delas os maridos compraram as alforrias de suas esposas; em duas, os filhos compraram a alforria das mães; em uma, a mãe comprou a alforria da filha; em uma, a irmã comprou a alforria do irmão; em uma, um pai comprou a alforria de sua filha; em uma o noivo (livre) comprou a alforria de sua noiva. (Lacerda, 2006, p.71).

Para Mariana, encontramos um caso bastante interessante e que exemplifica a luta de um pai para conquistar a alforria da filha. A menina Eva, cabra, de mais ou menos 14 anos em 1865, era filha natural de Antônio Bernardo da Rocha e foi beneficiada com a alforria após seu pai entregar o correspondente ao valor de Rs. $200 \$ 000$ - quantia paga na forma de um burro que valia Rs. $80 \$ 000$ e Rs $120 \$ 000$ em dinheiro. A maior parte do valor em dinheiro resultou de esmolas acumuladas pela madrinha de Eva, dona Basília Teixeira de Mesquita,

que desejando libertar a uma afilhada sua ainda inocente de nome Eva e, não podendo fazer por si por ser pobre, recorre a todas as pessoas pedindo uma esmola para por meio destas preencher esta obra de caridade. ${ }^{36}$

36 Arquivo da CSM, I Ofício, Códice 448, auto 9675. 
O processo elenca uma lista de pessoas que participaram da ação para arrecadar fundos para a compra da liberdade da menina Eva. Arrecadado o valor correspondente, Joaquim de Freitas Ferreira, o proprietário, passou-lhe carta de alforria por ser o trato entre ele e o pai da cativa.

A mencionada escravinha ficou forra dando Rocha o burro de cela e Rs. $20 \$ 000$ que perfaz a quantia de Rs.100\$000 (...) e que a madrinha tinha dado Rs. $100 \$ 000$ que tinha pedido de esmolas que perfaz a quantia de Rs. $200 \$ 000$ e que ele Freitas a libertava por esse preço em que ela foi avaliada no inventário da sua mãe. ${ }^{37}$

A maioria das alforrias que envolveram grupos familiares foi concedida sob alguma condição, especialmente aquelas que envolviam serviços, que normalmente eram prestados até a morte do senhor.

\section{Considerações finais}

Foram 425 cartas de alforria escrituradas nos cartórios dos I e II ofícios do termo de Mariana entre os anos de 1840 e 1888 que compuseram o principal do corpus documental desta pesquisa. Por sua análise, examinamos as variações na outorga da manumissão em uma conjuntura de sucessivos abalos no sistema escravagista através das leis abolicionistas, que, pouco a pouco, alteravam as regras do jogo e, por conseguinte, construíam novos perfis da alforria e do alforriado.

A queda da quantidade de registros de alforrias a partir de 1850 é um exemplo de consequência direta do surgimento das leis abolicionistas. A literatura sobre o tema demonstra que a lei que coibiu de vez a entrada de africanos como escravos no Brasil resultou na carestia dos preços dos mancípios e intensificação do tráfico interno, que desviou a mão de obra servil das regiões de economia menos mercantilizada para aquelas com produção voltada para a exportação; portanto, menos escravos, menos alforrias. Tanto a quantidade de inventários post-mortem que continham escravos, quanto a de escravos

\footnotetext{
${ }^{37}$ Arquivo da CSM, I Ofício, Códice 448, auto 9675.
} 
listados nesses inventários corroboram a ideia ao decair em número ao longo das décadas. Sobretudo nos anos 1880. E, ainda creditando boa parte desse movimento à transferência de cativos para regiões economicamente mais dinâmicas, não se deve minorar a importância dos efeitos das leis de 1871 e 1885. Além disso, libertar tornou-se mais custoso com menos oferta de mão de obra.

No geral, o perfil do alforriado de Mariana está próximo dos apresentados pela historiografia: favorecimento de mulheres; predomínio dos crioulos; elevado percentual de crianças e velhos. O contingente cativo marianense caracterizava-se, a princípio, por uma população com traços de participação do tráfico internacional em sua formação (grande maioria de homens e grande participação de africanos); mas, ao longo das décadas, vai-se tornando um conjunto com peculiaridades de reprodução endógena (mais equilíbrio entre os sexos e baixa porcentagem de africanos). A forte presença de crianças por todo o período estudado, entretanto, sugere que a reprodução endógena foi estratégica para a manutenção da escravaria mesmo durante a possibilidade do tráfico.

As mulheres eram um pouco mais alforriadas que os homens. Por todo o período e, separadamente, em quase todas as décadas. $\mathrm{O}$ fato em si teria pouca relevância não fosse a comparação com o contingente cativo total: as taxas de representação por gênero são inversamente proporcionais entre alforriados e população cativa total. Este dado não determina que o gênero fizesse diferença na decisão de emancipar ou não, pois uma das principais argumentações sobre esta constatação é de que os preços das mulheres eram menores e, por isso, havia mais facilidade em juntar o pecúlio necessário. Não se deve subestimar, entretanto, que a mulher escrava estabelecia laços afetivos com seus senhores e senhoras com muito mais facilidade, sobretudo as que exerciam funções domésticas e de ama de leite, e que também formavam mais frequentemente laços familiares no cativeiro.

As crianças tiveram grande participação entre os aforrados em Mariana: reflexo direto da alta representação infantil na população total - cerca de um terço da amostragem. As cartas cujos protagonistas são crianças contêm muitas justificativas de teor afetivo: "amor por tê-lo criado" ou "pelo amor que tenho adquirido" ou "pelo grande amor e parentesco espiritual". 
Homens e mulheres entre 15 e 44 anos receberam cerca de metade das alforrias. Mais uma vez, a proporção da categoria entre os alforriados reflete aproximadamente a mesma entre o contingente cativo total. O peculiar nesta faixa etária está no fato de deter a maior disparidade entre mulheres e homens emancipados.

Outra faixa etária digna de nota é a dos escravos com mais de 44 anos, representando cerca de um quinto dos alforriados. A idade avançada, a saúde debilitada e o cumprimento da lei (após 1885) serviram de explicação no texto de algumas cartas que tratavam dos maiores de 44 anos, mas o que arrazoou a manumissão destes homens e mulheres com maior frequência pode ser sintetizado em uma expressão: "retribuição aos serviços prestados ao longo da vida".

Quanto à origem dos alforriados, em conformidade com a historiografia para outras localidades, os crioulos estão em larga maioria. Considerando a partição dos forros por origem e sexo, africanos e crioulos, aparentemente, tinham grandes diferenças: entre os africanos, os homens foram maioria nos registros; entre os crioulos, ao contrário, a prevalência era das mulheres. Uma observação mais profunda, no entanto, reforça a posição privilegiada da mulher nas cartas de alforria. Sopesando as idades, os africanos viam aumentadas as chances de liberdade quanto mais velhos ficavam; os crioulos, de forma adversa, eram tornados forros com mais constância quando mais novos.

Cerca de um quarto dos escravos libertos teve descrita a filiação (em $90 \%$ dos casos, apenas a mãe foi revelada). As alforrias mantiveram juntos 39 grupos familiares: 23 eram de mãe e filhos; 10, de casais com filhos; e seis formados por irmãos. Na maior parte das vezes, em alforrias com grupos familiares, exigiu-se alguma condição a ser cumprida para a libertação (em especial, prestação de serviços até a morte do senhor). 


\section{Referências}

ALMEIDA, Kátia Lorena Novais. Alforrias em Rio de Contas-Bahia século XIX. Dissertação (Mestrado em História) - Universidade Federal da Bahia, Salvador, 2006.

BERTIN, Enidelce. Alforrias na São Paulo do século XIX: liberdade e dominação. São Paulo: Humanitas, 2004.

BOTELHO, Tarcísio Rodrigues. As alforrias em Minas Gerais no século XIX. LPH - Revista de História (UFOP), Ouro Preto, v. 6, p. 191-199, 1996.

CUNHA, Manuela Carneiro da. Sobre os silêncios da Lei: lei costumeira e lei positiva nas alforrias de escravos no Brasil no século XIX. In: São Paulo: Ed. Brasiliense, 1986. . Antropologia do Brasil-mito, história, etnicidade.

DIRETORIA GERAL DE ESTATÍSTICA. Recenseamento Geral do Império de 1872. Disponível em: http://www.biblioteca.ibge.gov.br/coleção_digital_publicacoes.php. Acesso em: 7 de abr. 2011.

EISENBERG, Peter L. Ficando livre: as alforrias em Campinas no século XIX. Estudos Econômicos, São Paulo, v. 17, n. 2, p. 175-216, 1987.

FERRAZ, Lizandra Meyer. Testamentos, alforrias e liberdade: Campinas, século XIX. Monografia (Bacharelado em História) - Universidade Estadual de Campinas, Campinas, 2006.

FLAUSINO, Camila Carolina. Negócios da escravidão: tráfico interno de escravos em Mariana (18501886). Dissertação (Mestrado em História) - Instituto de Ciências Humanas da Universidade Federal de Juiz de Fora, Juiz de Fora, 2006.

FONER, Eric. O significado da liberdade. Revista Brasileira de História, São Paulo, v.8, n. 16, mar./ ago., 1988.

GONÇALVES, Andréa Lisly. As margens da liberdade: estudo sobre a prática de alforrias em Minas colonial e provincial. Belo Horizonte: Fino Traço, 2011.

GORENDER, Jacob. O escravismo colonial. São Paulo: Ática, 1985.

KARASCH, Mary. A carta de alforria. In: São Paulo: Companhia das Letras, 2000.

KLEIN, Herbert S. Novas interpretações do tráfico de escravos do Atlântico. Revista de História. São Paulo, n. 120, jul. 1989.

LACERDA, Antônio Henrique Duarte. Os padrões das alforrias em um município cafeeiro em expansão: Juiz de Fora, zona da mata de Minas Gerais, 1844-1888. São Paulo: Annablume, 2006.

LUNA, Francisco Vidal \& KLEIN, Herbert S. Escravismo no Brasil. São Paulo: Edusp, 2010.

LUNA, Francisco Vidal \& KLEIN, Herbert S. Características da população em São Paulo no início do século XIX. População e Família. São Paulo, n. 3, p. 71-91, 2000.

MACHADO, Cláudio Heleno. Tráfico interno de escravos na região de Juiz de Fora na segunda metade do século XIX. In: SEMINÁRIO DE ECONOMIA MINEIRA, 10, Diamantina. Anais..., 2002.

MARQUESE, Rafael de Bivar. A dinâmica da escravidão no Brasil: resistência, tráfico negreiro e alforrias, séculos XVII a XIX. Novos estudos - CEBRAP. São Paulo, n. 74, mar., 2006.

MARTINS, Maria do Carmo Salazar. Revisitando a Província: Comarcas, Termos, Distritos e população de Minas Gerais em 1833-35. In: PAIVA, Clotilde Andrade \& LIBBY, Douglas Cole. 20 anos do Seminário sobre a Economia Mineira (1982-2002). Belo Horizonte: Cedeplar, 2002.

MATTOS, Hebe Maria. Das cores do silêncio: os significados da liberdade no sudeste escravista - Brasil, século XIX. Rio de Janeiro: Nova Fronteira, 1995.

MATTOSO, Kátia de Queirós. Ser escravo no Brasil. São Paulo: Brasiliense, 1990.

MOTTA, José Flavio. Escravos daqui, dali e de mais além: o tráfico interno de cativos em Constituição (Piracicaba), 1861-1880. Revista Brasileira de História. v.26, n.52, p. 15-47, São Paulo, 2006. 
PIRES, Maria de Fátima Novaes. Cartas de alforria: "para não ter o desgosto de ficar em cativeiro". Revista Brasileira de História. v. 26, n. 52, São Paulo, dezembro de 2006.

SCHWARTZ, Stuart. Segredos internos: engenhos e escravos na sociedade colonial (1550-1835). São Paulo: Companhia das Letras, 1988.

SLENES, Robert. Senhores e subalternos no Oeste paulista. In: ALENCASTRO, Luiz Felipe de. História da vida privada no Brasil: Império. 7a reimpressão. São Paulo: Companhia das Letras, p. 233-290, 2004.

Grandeza ou decadência? O mercado de escravos e a economia cafeeira da província do Rio de Janeiro, 1850-1888. p. 103-155. In: COSTA, Iraci del Nero da. (org.) Brasil: História Econômica e Demográfica. São Paulo: IPE/USP, 1986.

REIS, Isabel Cristina Ferreira dos. A familia negra no tempo da escravidão: Bahia, 1850-1888. Tese (Doutorado em História) - Universidade de Campinas, 2007.

. Histórias de vida familiar e afetiva de escravos na Bahia do século XIX. Salvador: Centro de Estudos Baianos, 2001.

REZENDE, Irene Nogueira de. Negócios e participação política: os fazendeiros da Zona da Mata de Minas Gerais (1821-1841). Tese (Doutorado em História) - Faculdade de Filosofia, Letras e Ciências Humanas da Universidade de São Paulo, 2008.

TEIXEIRA, Heloísa Maria. Reprodução e famílias escravas em Mariana (1850-1888). Dissertação (Mestrado em História) - Faculdade de Filosofia, Letras e Ciências Humanas da Universidade de São Paulo, 2001. . Livres, porém escravos: o injusto cativeiro e a luta de uma família negra pela liberdade (Mariana, século XIX). In: ENCONTRO REGIONAL DE HISTÓRIA, Belo Horizonte. Anais... Belo Horizonte, Anpuh-MG, 2009.

. Injusto cativeiro: a luta dos africanos pela liberdade (Mariana, segunda metade do século XIX).

In: ENCONTRO REGIONAL DE HISTÓRIA, Mariana. Anais... Mariana, Anpuh-MG, 2012. 